\title{
MUSIK TRADISIONAL KURIDING DI DESA ULU BENTENG KECAMATAN MARABAHAN KABUPATEN BARITO KUALA: BENTUK DAN FUNGSI PERTUNJUKAN
}

\author{
Muhammad Budi Zakia Sani \\ Universitas Lambung Mangkurat \\ E-mail: mbudizakiasani@ulm.ac.id
}

\begin{abstract}
Abstrak
Penelitian ini bertujuan untuk mengetahui bagaimana sejarah lahir dan perkembangan Musik Tradisional Kuriding di Desa Ulu Benteng Kecamatan Marabahan Kabupaten Barito Kuala. Metode penelitian yang digunakan yaitu deskriptif kualitatif dengan instrumen yaitu peneliti, perekam suara, kamera dan video. Teknik pengumupulan data yang dilakukan adalah studi lapangan atau observasi, studi dokumentasi, dan wawancara. Analisis data menggunakan teknik deskriptif analisis dengan tahap pengumpulan data, klasifikasi, dan deskripsi data serta analisis data. Hasil penelitian menunjukan bahwa Syamsudin (Alm) adalah orang yang pertama kali memainkan atau sebagai maestro kuriding di desa tersebut, berdasarkan paparan oleh Iwie, kuriding pertama kali ia ketahui setelah ia menikah dengan Syamsuddin sekitar tahun 1930an. Perkembangan kuriding di desa Ulu Benteng tidak mengalami perkembangan. Kuriding mengalami kemunduran dan hanya ditemukan empat orang saja yang masih bisa memainkan Kuriding dengan fakta mereka tidak mampu membuat alat musik tersebut. Bentuk musik kuriding ini adalah pertunjukan yang dilakukan secara perorangan atau kelompok. Fungsi musik yang terdapat dalam musik kuriding diantara adalah sebagai sarana hiburan pribadi, sebagai sarana presentasi estetis, dan juga sebagai sarana pengikat solidaritas masyarakat.
\end{abstract}

Kata Kunci: Kuriding, Musik Tradisional, Bentuk dan Fungsi Pertunjukan

\section{KURIDING TRADITIONAL MUSIC IN ULU BENTENG VILLAGE, MARABAHAN DISTRICT, BARITO KUALA REGENCY: FORM AND FUNCTION OF PERFORMANCE}

\begin{abstract}
The purpose of this study is to trace the history of Kuriding Traditional Music in Ulu Benteng Village, Marabahan District, Barito Kuala Regency. The method of study involves descriptive qualitative instruments, such as researchers, voice recorders, cameras, and videos. Field studies or observations, documentation studies, and interviews were all utilized to obtain data. Data analysis employs descriptive analytic techniques during the data collection, classification, and description stages of data collecting and analysis. The findings indicated that Syamsudin (Alm) was the first individual in the village to play or serve as a maestro of kuriding. According to Iwie, the first kuriding was known following her marriage to Syamsuddin in the 1930s. Kuriding's development in Ulu Benteng village remained stagnant. Kuriding suffered a setback when they discovered just four persons who could still play Kuriding due to their inability to manufacture the instrument. This style of kuriding music can be played solo or in groups. Kuriding music serves a variety of goals, including personal entertainment, aesthetic presentation, and community solidarity.
\end{abstract}

Keywords: Kuriding, Traditional Music, Form and Functions of Performance 


\section{A. PENDAHULUAN}

Musik tradisi adalah musik yang lahir dan berkembang di suatu daerah tertentu dan diwariskan secara turun-temurun dari satu generasi ke generasi berikutnya. Musik tradisional mempunyai ciri khas pada suatu suku atau lapisan masyarakat bangsa tertentu, dan nada-nadanya dimainkan dan diciptakan oleh alat-alat musik tradisional, yaitu alat musik yang mempunyai silsilah sejarah dan tradisi untuk lapisan masyarakat tertentu yang mempunyai ciri khas dan jati diri.

Musik tradisional biasa digunakan dalam upacara adat, upacara keagamaan, dan juga hiburan. Alat musik tradisional itu sendiri memiliki keunikan masing-masing, keunikan tersebut bisa nampak terlihat dari teknik memainkannya, penyajiannya, maupun bentuk/ organologi instrumen musiknya. Seni tradisonal itu sendiri mempunyai semangat kolektivitas yang tinggi, sehingga dapat dikenali karakter dan ciri khasnya pada masyarakat yang memiliki kesenian tersebut.

Musik tradisional kuriding atau yang disebut juga guriding yang dapat ditemukan di dalam Bahasa Bakumpai (Rangga 2011:57) adalah sebuah jenis kesenian musik tradisional Kalimantan selatan yang dapat disejajarkan posisinya dengan musik tradisional lainnya, seperti musik panting, gamelan banjar, kurung-kurung, bumbung, salung, kintung dan lain-lain. Kuriding ini biasanya dimainkan oleh satu orang atau bisa juga dimainkan oleh beberapa orang secara bersamaan. Cara memainkan alat musik ini adalah dengan cara disentak hingga menimbulkan suara dari alat musik itu sendiri. Bahan yang digunakan untuk membuat alat musik ini adalah sebuah kayu yang disebut dengan kayu bengaris, kayu ini biasa ditemukan di daerah hulu Barito atau Sungai Barito, namun saat ini kayu ini sudah sangat jarang ditemukan. Namun pada bahan lain yang bisa digunakan sebagai bahan dasar yaitu pelepah enau atau hanau. Kuriding biasanya dimainkan pada saat sedang disawah untuk melepas kepenatan selama bertani, Dan kuriding ini memiliki mitos dapat mengusir binatang buas yang berwujud Macan, yang mana Macan itu tidak akan berani jika Macan tersebut mendengar bunyi Kuriding ketika dimainkan karena memang sudah menjadi sumpahnya bahwa ia tidak tidak akan melihat Kuriding tersebut apalagi bahkan sampai mendengar bunyinya.

Desa Ulu Benteng adalah salah satu desa yang terdapat di kota Marabahan, tepatnya di kecamatan Marabahan kabupaten Barito Kuala, di desa ini merupakan salah satu situs keberadaan musik kuriding yang ada di Kalimantan Selatan yang dapat ditemui keberadaannya. Musik Kuriding di desa Ulu Benteng sudah ada dan berkembang sejak zaman dahulu hingga sekarang. Sampai saat ini masih bisa ditemukan dan ada tiga orang yang masih mampu memainkannya, walau mereka tidak mampu untuk membuat alat musik tersebut. Hal inilah yang dapat menyebabkan keberadaan dan perkembangan alat musik ini ke depannya mengalami kepunahan atau kemunduran, dikarenakan pembuat alat musik tersebut sudah tidak ada lagi.

Seiring dengan perkembangan zaman musik Kuriding ini dapat diapresiasi lebih jauh, yaitu hal yang perlu diketahui secara mendalam tentang musik Kuriding tersebut. Hal tersebut adalah mengenai awal keberadaan dan perkembangan alat musik kuriding tersebut Desa Ulu benteng khususnya dan di Kalimantan Selatan pada umumnya.

Mengetahui sejarah sebuah kesenian tradisional dimaksudkan agar masyarakat tidak hanya sekedar menikmati musik tersebut, tetapi masyarakat juga dapat mengetahui dan mengenal secara lebih mendalam mengenai asal-usul dan sejarah timbulnya kesenian $\mathrm{Ku}-$ riding di desa Ulu Benteng tersebut. Begitu juga dengan para pelaku seninya, mereka tidak hanya mampu memainkan alat musik tersebut tetapi juga mengetahui tentang sejarah dan asal-usul kesenian yang mereka bawa- 
kan. Pengetahuan tentang sejarah kesenian musik tradisional ini diperlakukan agar kita lebih bisa untuk menghargai dan senantiasa menjaga khasanah nilai-nilai budaya yang terkandung dalam kesenian tradisional Kuriding tersebut.

Sejarah sebuah kesenian dapat dijadikan sebagai sarana pewarisan kepada generasi selanjutnya. Sejarah juga dapat menjadi bukti masa lampau yang memberi gambaran tentang bagaimana mereka menjaga dan melestarikan kesenian mereka dan menjadi tolak ukur bagi perkembangan kesenian tersebut dihari yang akan datang.

Musik Tradisional Kuriding adalah salah satu kesenian yang layak untuk mendapat perhatian, sehingga keberadaannya dapat terus dipertahankan, dilestarikan dan tidak kalah dengan kesenian-kesenian lainnya serta terkikis oleh perkembangan zaman dan teknologi. Selain itu, kesenian tradisional seperti ini perlu untuk dituangkan dalam bentuk tulisan karya ilmiah sehingga sejarah dan keberadaannya dapat terus diketahui khususnya bagi masyarakat Ulu Benteng dan bagi masyarakat Kalimantan Selatan pada umumnya.

Peneliti mengambil Musik Tradisional Kuriding di desa Ulu Benteng ini sebagai objek penelitian kerena pentingnya sejarah sebuah kesenian Kuriding ini untuk diketahui, dengan diketahui sejarah musik ini maka akan menjadi identitas atau asal-usul daripada kesenian tersebut. Dan dengan diketahuinya sejarah musik tersebut maka perkembangan daripada alat musik akan dapat diketahui dari sejak ada dahulunya hingga sekarang.

Rumusan masalah dalam penelitian ini adalah pertama, bagaimana bentuk musik tradisional kuriding yang ada di desa Ulu Benteng Kecamatan Marabahan Kabupaten Barito Kuala. Kemudian yang kedua adalah bagaimana fungsi pertunjukan di dalam musik tradisional kuriding di desa Ulu benteng Kecamatan Marabahan Kabupaten Barito Kuala.
Adapun tujuan penelitian dalam tulisan ini adalah untuk mengetahui bentuk musik tradisional kuriding di desa Ulu Benteng Kecamatan Marabahan Kabupaten Barito Kuala. Dan juga untuk mengetahui fungsu pertunjukan musik tradisional kuriding di desa Ulu Benteng Kecamatan Marabahan Kabupaten Barito Kuala.

Tinjauan pustaka dalam penelitian ini memakai 2 konsep teori yang secara garis besar merupakan pisau bedah untuk menjawab rumusan masalah di dalam penelitian ini. kedua teori ini diambil untuk menjadi kerangka acuan teori yang digunakan dalam penelitian ini.

Menurut R.M Soedarsono (2001: 170171) dalam mengkaji sebuah seni pertunjukan dikla sifikasikan dalam tiga fungsi primer yaitu : (1) Sebagai sarana ritual yang penikmatnya adalah kekuatan yang tak kasat mata; (2) Sebagai sarana hiburan pribadi; (3) Sebagai sarana presentasi estetis, sedangkan fungsi sekunder terdiri dari : (1) Sebagai sarana pengikat solidaritas masyarakat; (2) Sebagai sarana pembangkit rasa solidaritas bangsa; (3) Sebagai media komunikasi; (4) Sebagai media propaganda agama; (5) Sebagai media propaganda politik; (6) Sebagai media propaganda pemerintah; (7) Sebagai media meditasi; (8) Sebagai sarana terapi; (9) Sebagai perangsang produktifitas).

Tidak semua fungsi berkaitan, nantinya hanya yang relevan saja yang akan diambil sebagai tolak ukur perubahan yang terjadi dari aspek fungsi musik tradisional kuriding di desa Ulu Benteng Kecamatan Marabahan Kabupaten Barito Kuala. Kerangka konseptual dari penelitian ini adalah untuk mengetahui, memaparkan, dan mendeskripsikan secara lebih merinci mengenai keberadaan, eksistensi, bentuk dan fungsi pertunjukan musik tradisional Kuriding di desa Ulu Benteng Kecamatan Marabahan Kabupaten Barito Kuala. 


\section{B. METODE}

Metode penelitian dapat diartikan sebagai cara ilmiah untuk mendapatkan data yang valid dengan tujuan dapat ditemukan, dikembangkan, dan dibuktikan, suatu pengetahuan tertentu sehingga pada gilirannya dapat digunakan untuk memahami, memecahkan, dan mengantisipasi masalah dalam bidang pendidikan (Sugiyono 2010:6).

\section{Pendekatan dan Jenis Penelitian}

Pendekatan penelitian yang digunakan adalah dengan menggunakan metode penelitian kualitatif. Metode ini digunakan untuk meneliti kondisi objek yang alamiah, yaitu objek yang berkembang apa adanya tanpa manipulasi oleh peneliti dan kehadiran peneliti tidak mempengaruhi objek tersebut. Penelitian kualitatif bersifat deskriptif, yaitu mengumpulkan data dengan cara terjun langsung ke dalam objek penelitian tersebut, data-data yang dikumpulkan yaitu berupa gambar-gambar, dan wawancara langsung dengan narasumber. Dengan menggunakan penelitian kualitatif ini maka data yang didapat akan lebih lengkap, mendalam, kredibel, dan bermakna mengenai objek penelitian.

Penelitian dengan pendekatan kualitatif merupakan multi metode yang fokus, melibatkan interpretasi, pendekatan, alamiah pada materi subjektif. Penelitian kualitatif merupakan studi yang menggunakan dan mengkoleksi variasi materi-materi empiris, studi kasus, pengalaman personal, introspektif, life history, interview, observasi, sejarah, interaksional, dan teks visual yang menggambarkan rutinitas dan problem waktu dan arti hidup individual (Pradoko 2017: 3).

\section{Instrumen Penelitian}

Instrumen penelitian dalam penelitian ini adalah si peneliti sendiri. Peneliti sebagai peneliti kualitatif berusaha menggali data berdasarkan apa yang diucapkan, dirasakan, dan dilakuakan oleh partisipan atau sumber data.
Penelitian bersifat "perspektif emic" artinya memperolah data bukan sebagaimana seharusnya, bukan berdasarkan apa yang dipikirkan oleh peneliti, melainkan sebagaimana adanya yang terjadi di lapangan, yang dialami, dirasakan, dan dipikirkan oleh partisipan atau sumber data (Sugiyono 2010 :295296).

\section{Lokasi Penelitian}

Lokasi penelitian dilakukan di Desa Ulu Benteng kecamatan Marabahan kabupaten Barito Kuala. Alasan pemilihan lokasi ini untuk dijadikan lokasi penelitian karena lokasi ini merupakan salah satu daerah atau situs keberadaan musik Kuriding ini, dan juga sampai saat ini kesenian ini masih dapat ditemukan para seniman pelakunya di desa Ulu Benteng tersebut. Oleh karena itu, lokasi penelitian ini berfokus di desa Ulu Benteng kecamatan Marabahan kabupaten Barito Kuala Kalimantan Selatan.

\section{Waktu Penelitian}

Waktu penelitian dilakukan dalam perhitungan waktu yang proporsional untuk sebuah penelitian. Waktu penelitian dilakukan sekitar enam bulan lamanya. Dalam proses itu penelitian berlangsung secara natural dan alamiah berdasarkan dengan data yang ada di lapangan, sehingga data yang dihasilkan merupakan gambaran peristiwa yang benar adanya.

\section{Teknik Pengumpulan Data}

Teknik pengumpulan data merupakan salah satu faktor penting yang sangat mempengaruhi tingkat relevansi data. Untuk memperoleh data-data yang relevan dengan penelitian yang dilakukan, diperlukan teknik pengumpulan data dengan cara terjun dan aktif ke dalam objek penelitian untuk mendapatkan informasi secara langsung. Sesuai dengan bentuk pendekatan penelitian kualitatif dari sumber data yang digunakan, maka tek- 
nik pengumpulan data yang digunakan adalah dengan analisis dokumen, observasi dan wawancara.

Teknik pengumpulan data merupakan langkah yang paling utama dalam penelitian untuk mendapatkan data yang memenuhi standar data yang ditetapkan (Sugiyono, 2010:308). Jadi, untuk memperoleh data yang berhubungan dengan Musik Tradisional Kuriding di Desa Ulu Benteng Kecamatan Marabahan Kabupaten Barito Kuala, peneliti mengumpulkan beberapa data yang lebih dominan menggunakan teknik observasi (studi lapangan), wawancara dan studi dokumentasi.

a. Observasi

Bogdan, Taylor, dan DeVault (2016: 84) mengemukakan bahwa :

As a qualitative researcher, your role is to try to capture how people define their world or construct their reality. What you produce as a qualitative account of people's definitions, constructions, and perspectives has no absolute claim to scientific truth or to being the only version of the ways things are. Given this indisputable fact, however, personal relationships or ideological allegiances should not prevent you from telling the story as you see it and from your point of view (of course, acknowledging that this is your point of view.

Berdasarkan kutipan di atas berarti bahwa sebagai sebuah penelitian kualitiatif, tujuan anda adalah mencoba untuk mencari gambaran bagaimana orang menegaskan dunia mereka atau mengkonstruksikan realitas mereka. Apa yang kamu hasilkan sebagai sajian kualitatif dari definisi seseorang, konstruksi, dan sudut pandang yang tidak mengakui secara absolut tentang ilmu kebenaran atau membuat hanya satu jalan untuk segala sesuatu. Telah diberikan sebuah fakta yang tidak terelakkan, bagaimanapun, hubungan personal atau ideologi kesetian tidak akan mencegah kamu untuk menceritakan kisah seperti yang kamu lihat dan inti dari yang kamu dapatkan. Sehingga, kegiatan observasi adalah langkah yang paling awal dalam proses pengumpulan data. Observasi dilakukan untuk mencari gambaran awal tentang keseluruhan penelitian.

Rohidi (2012: 182) menyatakan bahwa teknik observasi adalah teknik yang digunakan untuk mengamati sesuatu, seseorang, suatu lingkungan, atau situasi secara tajam dan terinci, dan mencatatnya secara akurat dalam beberapa cara. Metode observasi dalam penelitian seni dilaksanakan untuk memperoleh data tentang karya seni dalam suatu kegiatan dan situasi yang relevan dengan masalah penelitian.

Pada tahap observasi ini, penulis melakukan pengamatan secara langsung. Peneliti terjun langsung ke lapangan untuk mendapatkan informasi, video, dan gambar-gambar tentang kesenian Kuriding di desa Ulu Benteng kecamatan Marabahan Barito Kuala. Observasi dilakukan untuk mendapatkan gambaran yang lebih jelas tentang sejarah dan perkembangan Musik Tradisional Kuriding di desa Ulu Benteng kecamatan Marabahan Barito Kuala.

\section{b. Wawancara}

Estenberg dalam Sugiyono, (2010:317) mendefinisikan wawancara sebagai pertemuan dua orang untuk bertukar informasi dan ide melalui Tanya jawab, sehingga dapat dikonstruksikan makna dalam suatu topic tertentu.

Dalam penelitian ini, peneliti akan melakukan tanya jawab secara langsung kepada orang yang dianggap dapat memberikan informasi tentang musik kuriding (informan). Wawancara ini dilakukan untuk mengadakan komunikasi dengan pihak-pihak terkait atau subjek penelitian, antara lain : 
1) Iwie, 90 tahun adalah seorang pemain kuriding yang merupakan istri dari Syamsudin Maestro pemain kuriding di Desa Ulu Benteng.

2) Rumiah, 50 tahun adalah salah seorang pemain kuriding di desa Ulu Benteng kecamatan Marabahan kabupaten barito Kuala.

3) Gafaruddin, 45 tahun adalah salah seorang pemain kuriding di desa Ulu Benteng kecamatan Marabahan kabupaten barito Kuala.

4) Abdiannor, 45 tahun adalah seorang warga desa Ulu Benteng yang bekerja di Dinas Pariwisata, Pemuda dan Olahraga Kabupaten Barito Kuala.

5) Drs. Mukhlis Maman, 53 tahun seorang seniman kuriding dan pembuat kuriding Kalimantan Selatan yang merupakan PNS Taman Budaya Kalimantan Selatan.

6) Ferry Kusmana, 30 tahun seorang aktivis kuriding di Kalimantan Selatan.

\section{c. Dokumentasi}

Dokumen merupakan catatan peristiwa yang sudah berlalu. Dokumen bias berbentuk tulisan, gambar, atau karya-karya monumental dari seseorang. Dokumen yang berbentuk tulisan misalnya catatn harian, sejarah kehidupan (life histories), ceritera, biografi, peraturan kebijakan. Dokumen yang berbentuk gambar, misalnya foto, gambar hidup, sketsa dan lain-lain. Dokumen yang berbentuk karya misalnya karya seni, yang dapat berupa gambar, patung, film, dan lain-lain. Studi dokumen merupakan pelengkap dari penggunaan metode observasi dan wawancara dalam penelitian kualitatif (Sugiyono, 2010:329)

Dalam penelitian ini peneliti memperoleh data dari hasil merekam dan mengambil gambar dengan menggunakan media dan peralatan berupa kamera foto atau video untuk mendapatkan gambar berupa foto dan video terkait data yang diperlukan peneliti. Dokumentasi dilakukan untuk mengumpulkan data yang bersumber dari arsip dan dokumen, baik yang berada di perpustakaan ataupun yang berada di luar yang memiliki hubungan dengan penelitian tersebut.

\section{Teknik Analisis Data}

Bogdan dalam Sugiyono (2010:334), menyatakan bahwa analisi data adalah proses mencari dan menyusun secara sistematis data yang diperoleh dari hasil wawancara, catatan lapangan, dan bahan-bahan lain, sehingga dapat mudah dipahami, dan temuannya dapat diinformasikan kepada orang lain. Analisis data dilakukan dengan mengorganisasikan data, menjabarkan ke dalam unit-unit, melakukan sintesa, menyusun ke dalam pola, memilih mana yang penting dan yang akan dipelajari, dan membuat kesimpulan yang dapat diceritakan kepada orang lain.

Data-data yang sudah dikumpulkan selanjutnya akan dianalisi dengan teknik deskriptif analisis. Hasil dari kumpulan data tersebut dirangkum dan disusun dengan tujuan penelitian yaitu mengetahui Musik Tradisional Kuriding di Desa Ulu Benteng Kecamatan Marabahan Kabupaten Barito Kuala. Langkah-langkah yang digunakan dalam analisis data, yaitu :

1) Mengumpulkan data

2) Reduksi data

3) Penyajian data

4) Verifikasi data atau penarikan kesimpulan

\section{Pengujian Keabsahan Data}

Untuk memperoleh keabsahan data, maka peneliti melakukan usaha-usaha yaitu diteliti kredibilitasnya dengan melakukan teknik-teknik sebagai berikut:

a. Perpanjangan pengamatan

Dengan perpanjangan pengamatan berarti peneliti melakukan pengamatan, wawancara lagi dengan sumber data atau menambah (memperpanjang) waktu untuk observasi. Wawancara yang awalnya hanya satu minggu, maka akan ditambah waktu satu minggu 
lagi. Dan jika dalam penelitian ini, data yang diperoleh tidak sesuai dan belum cocok maka dari itu dilakukan perpanjangan pengamatan untuk mengecek keabsahan data. Bila setelah diteliti kembali ke lapangan data sudah benar berarti kredibel, maka waktu perpanjangan pengamatan dapat diakhiri.

\section{b. Meningkatkan ketekunan}

Untuk meningkatkan ketekunan, peneliti bisa melakukan dengan sering menguji data dengan teknik pengumpulan data yaitu pada saat pengumpulan data dengan teknik observasi dan wawancara, maka peneliti lebih rajin mencatat hal-hal yang detail dan tidak menunda-nunda dalam merekam data kembali, juga tidak menganggap mudah / enteng data dan informasi. Dengan teknik dokumentasi, maka peneliti akan lebih tekun membaca referensi-referensi buku terkait dengan majelis pengajian sebagai wawasan peneliti untuk memeriksa kebenaran data.

\section{c. Triangulasi}

Triangulasi sumber data menguji kredibilitas ini diartikan sebagai pengecekan data (cek and ricek) dari berbagai sumber dengan berbagai cara dan berbagai waktu.

1) Triangulasi sumber, adalah untuk menguji kredibilitas data yang dilakukan dengan cara mengecek data yang telah diperoleh melalui beberapa sumber, pertama adalah narasumber Iwie berusia 90tahun, Rumaih berusia 45tahun, dan Gafarudin berusia 35tahun. Maksudnya apabila data yang diterima dari satu sumber adalah meragukan, maka harus mengecek kembali ke sumber lain, tetapi sumber data tersebut harus setara sederajatnya. Kemudian peneliti menganalisis data tersebut sehingga menghasilkan suatu kesimpulan dan dimintakan kesempatan dengan sumber-sumber data tersebut.
2) Triangulasi teknik, adalah untuk menguji kredibilitas data yang dilakukan dengan cara mengecek data kepada sumber yang sama dengan teknik yang berbeda, yaitu yang awalnya menggunakan teknik observasi, maka dilakukan lagi teknik pengumpulan data dengan teknik wawancara kepada sumber data yang sama dan juga melakukan teknik dokumentasi.

\section{HASIL DAN BAHASAN}

\section{Bentuk Musik Tradisional Kuriding Di Desa Ulu Benteng Kecamatan Ma- rabahan Kabupaten Barito Kuala.}

Musik kuriding merupakan salah satu kesenian tradisi rakyat. Kuridingdiinterpretasikan sebuah alat getar yang dapat dikategorikan sebagai alat musik ritmis/perkusi, berdasarkan dari hasil produksi suara, teknik cara memainkannya, dan termasuk ke dalam jenis musik idiofon (Najamudin, 2016).

Dalam kehidupan yang sudah menetap dan teratur dapat tercipta kesenian-kesenian yang bernilai tinggi. Diantara kesenian tersebut adalah Musik Kuriding. Musik Kuriding berpangkal pada kegiatan masyarakat zaman dahulu ketika pergi kesawah untuk bertani yang membawa Kuriding sebagai alat untuk mengusir binatang buas seperti Macan. Binatang buas tersebut tidak berani mengganggu jika mendengar bunyi Kuriding.

Menurut wawancara denegn narasumber Mukhlis Maman dalam kamus logat kecil bahasa indonesia Kuriding itu berasal dari dua kata yaitu kur yang berarti seruan atau menyeru/memanggil, dan riding yang berarti jala untuk menangkap sejenis binatang buas. Sehingga dapat di tarik pengertian, kuriding adalah seruan untuk membuat takut binatang buas.

Awal bermula musik kuriding di Desa Ulu Benteng yaitu berawal dari kepercaya- 
an masyarakat dahulu "urang bahari" terhadap seekor Datu Macan yang memainkan kuriding, kemudian ilat atau bubutuhan kuriding tersebut patah dan menyebabkan Datu Macan tersebut mati, sehingga ia bersumpah bahwa anak cucunya kelak jangan lagi mendekati apalagi memainkan kuriding tersebut. Dari situlah awal ketakutan Datu Macan dan keturunannya terhadap kuriding, sehingga dipercaya oleh masyarakat yang bepergian ke hutan atau berladang jika membawa kuriding dan memainkannya, maka hewan atau binatang buas berupa Macan tidak akan berani mendekat kepada mereka dan tidak akan mengganggu mereka.

Alat musik kuriding merupakan alat musik perkusi berdasarkan produksi suara dan cara memainkannya. Kuriding terbuat dari kayu bengaris yang tumbuh di daerah gunung di hulu sungai Barito. Alat musik ini berbentuk persegi panjang dengan ukuran panjang $10 \mathrm{~cm}$ dan lebar $2 \mathrm{~cm}$ dengan ketebalan $2 \mathrm{~mm}$ (Maryanto 2014: 36).

Seorang tokoh kuriding di Desa Ulu benteng yaitu bernama Syamsudin (Alm), yang merupakan suami dari narasumber utama saya yang bernama Iwie (90 tahun). Menurut Iwie, Syamsuddin adalah orang yang pertama kali memainkan Kuriding di Desa Ulu Benteng tersebut, Iwie pertama kali mengenal Kuriding sejak ia sudah menikah dengan Syamsuddin sekitar tahun 1930an. Pada saat itu kuriding yang dimiliki oleh Syamsudin hanya satu buah saja, kemudian ia mengajarkan cara bermain kuriding kepada Iwie dan ia membuat satu buah kuriding lagi untuk mereka mainkan bersama-sama. Namun Iwie tidak dapat menjelaskan lagi lebih detail mengenai bagaimana Syamsudin bisa bermain kuriding karena faktor keterbatasan ingatan dan usia Iwie yang sudah tua. Tetapi dari wawancara yang saya lakukan, Iwie menuturkan bahwa sebelum Syamsuddin menikah dengannya, Syamsuddin pernah madam atau merantau ke daerah lain yang tidak diketahui nama daerahnya, namun daerah tersebut tidak di luar pulau Kalimantan. Namun, satu hal juga yang menjadi pertimbangan saya, dimungkinkan Kuriding bisa juga dipengaruhi oleh kebudayaan lain karena pada zaman dahulu khususnya kota Marabahan, yang merupakan salah satu titik perdagangan air di Kalimantan Selatan pada saat itu, yang berjarak hanya sekitar $60 \mathrm{~km}$ dengan kota Banjarmasin dimana Sungai Barito adalah akses utamanya. Tidak menutup kemungkinan Kuriding ini masuk melalui arus perdagangan pada dahulunya sebagai alat tukar sehingga Kuriding tersebut ada di Desa Ulu Benteng.

Tahun awal penciptaan Musik kuriding tidak diketahui secara pasti, namun menurut tokoh-tokoh Musik Kuriding di Desa Ulu Benteng yang masih berkaitan darah dengan tokoh penciptaan Musik Kuriding menyebutkan bahwa bermain musik Kuriding tersebut sudah dilakukan sekitar tahun 1930an. Hal ini disebutkan berdasarkan cerita turun-temurun oleh keluarga pewaris musik kuriding tersebut dan dibuktikan dengan menarik mundur usia si maestro Kuriding almarhum Syamsuddin yang lahir tahun 1910, dimungkinkan kuriding ini ada sejak adanya juga sang maestro Kuridingnya yaitu sekitar tahun 1930an ketika Syamsuddin dianggap sudah berusia remaja, dan juga pada tahun-tahun setelah kemerdekaan yaitu tahun 1945 sudah diadakan acara bakuriding, dan juga dibuktikan dengan masih adanya peninggalan alat musik yang dimainkan sejak awal dahulunya, hingga sekarang yang masih dalam kondisi bisa dimainkan dan diperkirakan usia dari alat musik tersebut hampir mencapai seratus tahun karena dilihat dari warna kuriding tersebut yang sudah menghitam, tidak seperti kuriding yang baru. 


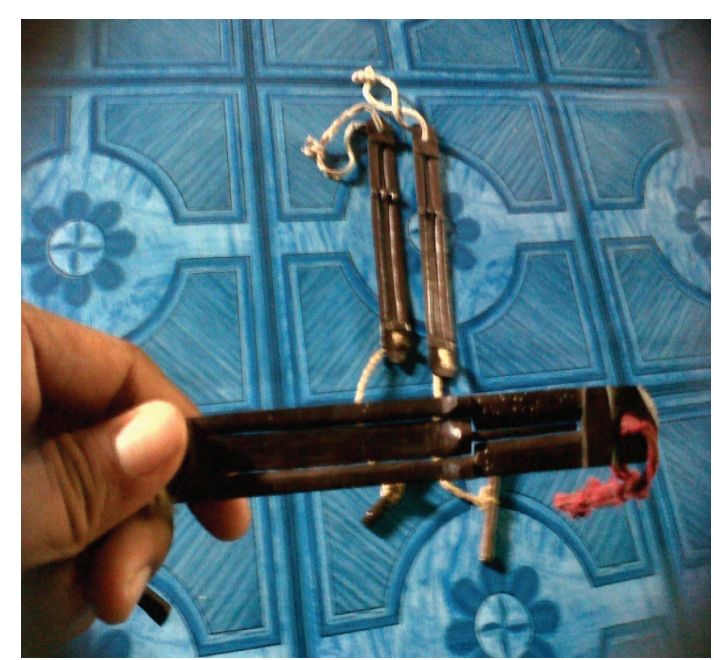

(Dokumentasi pribadi : M. Budi Zakia Sani 2014)

Menurut Gafarudin, Kuriding yang masih ada saat ini adalah memang betul-betul peninggalan dari almarhum ayahnya Syamsuddin. Kuriding tersebut diamanatkan oleh almarhum Syamsuddin kepada anak cucunya untuk tidak dijual kepada orang lain, dan terus dilestarikan oleh anak cucunya kelak.

Seiring perjalanan waktu kuriding tidak hanya dimainkan oleh Syamsudin dan Iwie, menurut Iwie pada saat itu banyak warga Ulu benteng yang belajar memainkan kuriding dan pada sekitar tahun 1960an merekan sudah mempunyai beberapa orang anak yang juga belajar bermain kuriding pada saai itu, yaitu diantaranya Rumiah (45 tahun) dan) Gafarudin (35 tahun)yang sampai saat ini mewarisi musik Kuriding tersebut.

Menurut Rumiah, pada zaman dahulu banyak warga yang berminat belajar Kuriding, tidak seperti sekarang, sudah banyak yang tidak peduli dan tidak berminat untuk belajar dan melestarikan kesenian daerah. Sehingga kemungkinan Kuriding ini tidak akan berkembang di desa Ulu Benteng tersebut.

Sampai saat ini masyarakat di kota Marabahan, khususnya Desa Ulu Benteng masih meminati musik kuriding. Namun keberadaan mereka saat ini yang mengkhawatirkan karena pelaku seni kuriding yang masih tersi- sa di Desa Ulu Benteng hanya tinggal 4 orang, yaitu Iwie (90 tahun) istri dari Syamsudin, Rumiah (45 tahun) anak dari Syamsudin, Gafarudin (35 tahun) anak dari Syamsudin), dan Badiyuni (40 tahun) warga desa Ulu Benteng yang masih berkeluarga dengan Syamsudin. Kurangnya minat dari generasi muda dan kurangnya perhatian dari pemerintah menyebabkan musik kuriding ini menjadi tidak berkembang di Ulu Benteng dan dapat dikatakan langka pada saat ini.

Musik Kuriding berbeda dengan musik tradisional lainnya di Kalimantan Selatan, seperti halnya Musik Panting dan Gamelan Banjar sudah mampu eksis dan berkembang mengikuti zaman, kuriding masih belum begitu terjamah dan diminati khususnya di Desa Ulu Benteng tersebut. Namun Kuriding ini memiliki nilai lebih tersendiri, Kuriding adalah alat musik yang unik, tidak semua orang mampu memainkannya layaknya Panting dan Gitar. Kuriding memiliki tingkat kesulitan tersendiri yang tidak dapat dimainkan oleh semua orang.

\subsection{Perkembangan Musik Kuriding Di Desa Ulu Benteng}

Kebudayaan yang berkembang pada masyarakat Bakumpai juga banyak mendapat pengaruh dari budaya Arab dan Melayu, seperti kesenian-kesianian daerah lainnya. Sehingga, emosi keagamaan masih begitu jelas dan nampak tercermin dalam kebudayaan masyarakat Bakumpai sehari-harinya, seperti masyarakat Banjar juga pada umumnya. Begitu juga halnya di Desa Ulu Benteng ini, masyarakatnya yang religius sangat menjunjung tinggi syariat Islam, walaupun ikatan kekerabatan mulai berkurang dibandingkan dengan masa yang lalu tetapi masyarakat pelaku seni musik kuriding selalu berusaha menjaga dan melestarikan kesenian ini agar terus ada dan berkembang.

Sampai saat ini kesenian musik kuriding masih tetap ada di Desa Ulu benteng, walau- 
pun keberadaannya sendiri kurang mendapatkan perhatian dari dan minat dari generasi penerusnya, sehingga dikhawatirkan musik kuriding ini akan mengalami kepunahan nantinya seperti kesenian-kesenian lainnya. Namun para seniman yang masih tersisa di Desa Ulu Benteng sampai saat ini hanya empat orang, mereka pun sekarang hanya bisa memainkan saja, mereka terdiri dari : Iwie (90 tahun), Rumiah (45 tahun), Gafaruddin (35 tahun), dan Badiyuni (40 tahun). Mereka tergabung dalam satu kelompok pemain kuriding yang merupakan satu-satunya kelompok yang ada di Desa Ulu Benteng.

Kelompok ini diawali oleh adanya musik kuriding ini di Desa Ulu Benteng sejak sekitar tahun 1930an, yaitu Syamsudin sang $m a-$ estro Kuriding dari Desa Ulu Benteng yang mengajarkan cara memainkan Kuriding kepada Iwie, kemudian dengan seiring waktu mereka mempunyai keturunan dan Syamsudin mengajarkan Kuriding lagi kepada anak-anaknya. Selain mengajarkan kepada anaknya, kuriding juga banyak diminati warga lainnya di Desa Ulu benteng pada dahulunya, dapat dibuktika menurut narasumber hampir seluruh warga Ulu Benteng saat itu mampu memainkan kuriding, sehingga pada saat itu kuriding menjadi familiar di ruang lingkup masyarakat Desa Ulu Benteng dan menjadi identitas masyarakat pelakunya.

Sekitar tahun 1960an sampai tahun 1990an kesenian kuriding ini mulai mendapat apresiasi dari pemerintah dan mulai ditampilkan dalan acara-acara besar seperti peringatan hari jadi kabupaten, pergelaran seni budaya oleh dinas terkait, mengisi acara hajatan warga dan lain-lain. Pada saat itu kuriding sudah mulai ditampilkan di dalam bentuk pagelaran musik dan memnggunakan kostum baju, yaitu baju kurung untuk perempuian da taluk balanga untuk laki-laki. Sehingga pada fase ini kuriding lumayan mengalami perkembangan di ruang lingkup kota Marabahan dan sekitarnya, khusunya warga
Desa Ulu Benteng. Dan hampir seluruh warga saat iti mampu memainkan Kuriding.

Namun, seiring dengan berkembangnya zaman dan teknologi, musik kuriding ini mengalami kemunduran sejak tahun 2000an hingga sekarang, dikarenakan kalah bersaing dengan kesenian lain dan majunya globalisasi dan moderenidasi zaman yang menyebabkan kuriding tidak lagi dimainkan di dalam keseharian masyarakatnya, hanya di mainkan pada waktu-waktu tertentu saja, misalnya pada acara-acara resmi pemerintahan seperti hari jadi kabupaten yang diadakan satu tahun sekali. Selain juga mata pencaharian masyarakat yang sebagian besar sudah tidak bertani lagi, masyarakat sudah banyak yang menjadi PNS, berdagang,merantau dan lain-lain sehingga menyebabkan kuriding sudah sangat jarang dimainkan oleh warga Ulu Benteng pada zaman sekarang ini.

Sampai saat ini kelompok Kuriding di Desa Ulu Benteng hanya memiliki empat orang yang bisa memainkan kuriding dan rata-rata usia mereka sudah tua dan belum ada regenerasi yaitu :

a. Iwie berusia 90 tahun yang merupakan istri dari Syamsudin maestro kuriding di Desa Ulu Benteng.

b. Rumiah berusia 45 tahun yang merupakan ank dari Syamsudin.

c. Gafarudin berusia 35 tahun yang merupakan anak dari Syamsudin.

d. Badiyuni berusia 40 tahun warga Ulu Benteng yang masih memiliki ikatan tali kekuarga dengan Syamsudin.

Menurut Abdiannoor warga Ulu Benteng yang merupakan pegawai di Dinas Pemuda Olahraga Kebudayaan dan Pariwisata Kabupaten Barito Kuala ada beberapa faktor yang menyebabkan kesenian Kuriding mengalami kemunduran di Desa Ulu Benteng yaitu :

a. Kurangnya minat dari generasi muda saat ini khususnya di Desa Ulu Benteng terhadap kesenian musik kuriding sehingga 
musik kuriding tidak menjadi berkembang

b. Kurangnya perhatian dan dukungan dari pemerintah setempat terhadap keberadaan kuriding dan seniman pelakunya sehingga mereka hanya secara swadaya melanjutkan dan melestarikan kesenian tersebut.

c. Mata pencaharian masyarakat yang mayoritas tidak bertani lagi menyebabkan kuriding jarang dipakai dan digunakan untuk sarana menghibur diri di saat bertani.

d. Kesulitan di dalam memainkan alat musik kuriding tersebut menyebabkan jarang orang yang mampu dan mahir memainkan kuriding tersebut.

e. Keterbatasan dana operasional seperti perawatan dan pengadaan alat serta kostum pemain. Selain juga ketidakmampuan mereka untuk membuat alat tersebut menyebabkan kuriding yang digunakan hanya kuriding yang diwariskan yang berjumlah 4 buah.



Gambar 1 : Kuriding(dokumentasi M. Budi Zakia Sani : 2014)

Kalau kita menampak bagian dalamnya, maka terlihat ada bagian yang cembung dan ada pula yang cekung. Bagian yang cembung terdapat pada kedua ujungnya dan bagian bagian tengah agak ke kiri. Di tengahnya ada alat getar yang memanjang. Alat ini terdiri dari dua bagian, yaitu yang di sebelah kanan disebut dengan ilat dan sebelah kirinya disebut bubutuhan. Perbandingan panjang antara ilat dan bubutuhan kuriding adalah 7 berbanding 3, bagian yang lebih besar adalh pada bagian ilat, sedangkan bubutuhan nya lebih kecil. Di sekeliling ilat dan butuh tersebut ada celah-celah sempit yang menurut istilah daerahnya adalah susungaian yang lebarnya kurang lebih $1 \mathrm{~mm}$. Fungsi dari susungaian itu adalah intuk ilat kuriding agar dapat bergetar jika ditarik.

Pada ujung sebelah kanan terdapat lobang kecil untuk tempat tali penariknya, yang biasanya terbuat dari tali sinali. Tali penarik ini menurut istilah daerah setempat disebut dengan tatarikan. Pada ujung tali tatarikan tersebut dikaitkan kayu yang dibulatkan sepanjang 4 sampai $5 \mathrm{~cm}$, dengan diameter kurang lebih $0,5 \mathrm{~cm}$, yaitu untuk mempermudah menariknya. sedangkan pada ujung sebelah kiri terdapat pula lobang kecil untuk tempat tali, yang kedua ujungnya diikat menjadi satu, hingga bentuknya seperti lingkaran. Tali tersebut untuk menahan tarikan dari tangan kanan yang disebut dengan gagang.

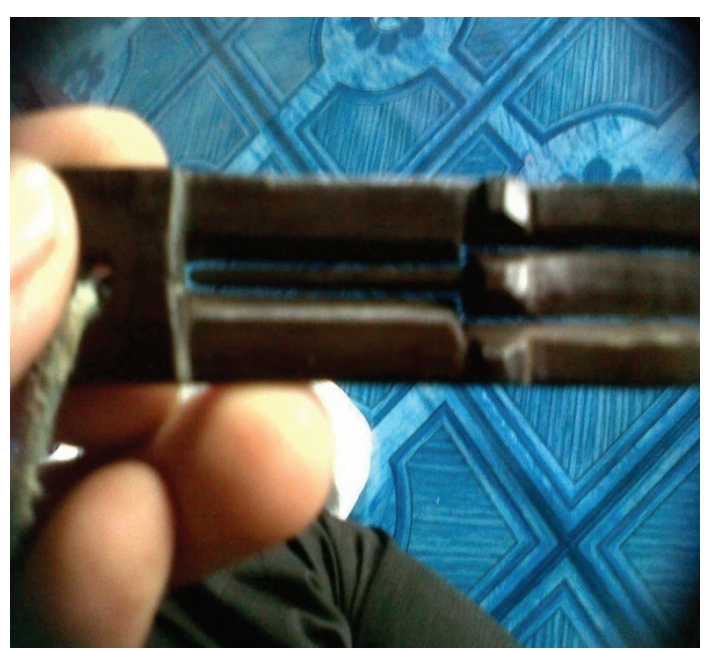

Gambar 2 : kuriding (dokumentasi M. Budi Zakia Sani : 2014) 
Pada zaman dahulu kuriding hanya berfungsi sebagai media untuk hiburan ketika sedang bertani di sawah. Kini kuriding sudah dipertunjukan pada kegiatan-kegiatan seni dan budaya. Diantaranya Pawai Budaya Dewan Kesenian Daerah Barito Kuala (2000), Festival Pasar Terapung (2010), Pekan Kemilau Seribu Sungai (2011), dan lain-lain.

Cara penyajian musik tradisional kuriding dapat ditampilkan di mana saja misalnya di pekarangan rumah, tanah lapang, lapangan besar, dan di panggung pertunjukan atau gedung. Para pemain kuriding memainkan kuriding dengan posisi bersila atau batalimpuh dengan posisi berjejer, dan menggunakan kostum baju taluk balanga untuk laki-laki dan baju kurung untuk perempuan. Seperti gambar di bawah ini.

Lagu dan Teknik Bermain Musik Tradisional Kuriding terdapat beberapa repertoar yang merupakan bentuk asli dan ada sejak awal keberadaannya, diantaranya adalah sebagai berikut:

a. Ayakan

Lagu ayakan menggunakan pola irama hitungan genap atau tanda sukat 4/4. Tempo yang dugunakan adalah tempo sedang, dalam bahasa musik disebut andante atau dianalogikan kecepatannya seperti orang berjalan. Semua ritme pada lagu ini menggunakan not-not $1 / 8$, dalam teori musik teori musik disebut setengah ketukan. Pada lagu ayakan biasanya komposisi dibawakan menyesuaikan dengan kehendak pemain. Nada dapat disimpulkan menjadi tiga wilayah bunyi, yaitu rendah, sedang, dan tinggi. Dalam bentuk ini tidak ada permainan dinamika seperti perubahan dari keras ke lembut ataupun sebaliknya dinamika dalam bentuk ini cenderung statis. Ayakan ini tidak mempunyai frase-frase baik tanya maupun jawab seperti bentuk lagu pada umumnya, jadi hanya berupa motif. Dalam penelitian ini penulisan notasi kuriding menggunakan single line atau satu garis. Perbedaan bunyi diatur oleh tinggi rendahnya penempatan nada.
Berikut merupakan contoh notasi komposisi ayakan:

\section{b. Tiukang}

Tiukang menggunakan pola irama hitungan genap 4/4 juga seperti lagu ayakan. Tempo yang digunakan adalah tempo sedang, dalam bahasa musik disebut andante. Semua ritme menggunakan not-not $1 / 8$, dalam teori musik disebut setengah ketukan. . Pada lagu tiukang biasanya komposisi dibawakan menyesuaikan dengan kehendak pemain. Nada dapat disimpulkan menjadi tiga wilayah bunyi, yaitu rendah, sedang, dan tinggi. Dalam bentuk ini tidak ada permainan dinamika seperti perubahan dari keras ke lembut ataupun sebaliknya dinamika dalam bentuk ini cenderung statis. Tiukang ini tidak mempunyai frase-frase baik tanya maupun jawab seperti bentuk lagu pada umumnya, jadi hanya berupa motif. Dalam penelitian ini penulisan notasi kuriding menggunakan single line atau satu garis. Perbedaan bunyi diatur oleh tinggi rendahnya penempatan nada.Pada bentuk ini biasanya diselipkan lagu yang berbentuk pantun. Berikut pantun lagu pada tiukang :

\section{Tiukang teluk telang \\ Batiti si puhun pinang \\ Juluk tanggui bi lalungkang \\ Ujan labat sanja kala tukup pijem \\ Arti dari pantun tersebut : \\ Burung tiukang di kampung teluk telang \\ Berjalan di pohon pinang \\ Memberi tanggui dari jendela \\ Hujan lebat pada waktu hari senja kuning atau gelap gulita}

Dan berikut notasi komposisi lagu tiukang :

\section{c. Sabulu tinjau}

Lagu Sabulu-bulu tinjau menggunakan pola irama hitungan genap atau tanda sukat 4/4. Tempo yang dugunakan adalah tempo sedang, 
dalam bahasa musik disebut andante atau dianalogikan kecepatannya seperti orang berjalan. Semua ritme pada lagu ini menggunakan notnot $1 / 8$, dalam teori musik teori musik disebut setengah ketukan. Pada lagu ini biasanya komposisi dibawakan menyesuaikan dengan kehendak pemain. Nada dapat disimpulkan menjadi tiga wilayah bunyi, yaitu rendah, sedang, dan tinggi. Dalam bentuk ini tidak ada permainan dinamika seperti perubahan dari keras ke lembut ataupun sebaliknya dinamika dalam bentuk ini cenderung statis. Lagu ini tidak mempunyai frase-frase baik tanya maupun jawab seperti bentuk lagu pada umumnya, jadi hanya berupa motif. Dalam penelitian ini penulisan notasi kuriding menggunakan single line atau satu garis. Perbedaan bunyi diatur oleh tinggi rendahnya penempatan nada.

Pada bentuk ini juga terdapat lagu atau pantun yang bunyinya seperti berikut :

\section{Sabulu bulu tinjau \\ Tinjau rarutan \\ Batapih karung hijau \\ Ulih mancuntan \\ Arti dari pantun tersebut adalah : \\ Seekor burung tinjau yang berbulu elok \\ Yaitu burung tinjau rarutan \\ Memakai sarung warna hijau \\ Karena akibat mencuri}

Dan berikut mepakan notasi dari lagu sabulu bulu tinjau :

\section{d. Radut-radut}

Lagu radut- radut adalah lagu yang sudah tidak dimainkan lagi, karena keterbaatasan ingatan para seniman pewaris kuriding sehingga lagu ini tidak ada ya $\mathrm{g}$ bisa memainkan lagi.

\section{e. Dompet tumbang betong}

Lagu ini juga merupakan salah satu lagu yang sudah tidak dimainkan lagi karena keterbatasan ingatan pemain kuriding sehingga lagu ini tidak dapat lagi dimainkan.

\section{f. Kalana}

Lagu ini merupakan lagu yang diambil dari lagu gamelan yaitu lagu untuk mengiringi tari, namun lagu ini sudah tidak dapat dimainkan lagi karena keterbatasan ingatan para pemain kuriding, atau sudsah lupa dengan bentuk lagu ini.

\section{g. Paparangan}

Lagu ini juga mengambil lagu pada gamelan banjar, namun lagu ini juga sudah termasuk lagu yang tidak dimainkan lagi karena keterbatsan ingatan para pemain kuriding.

\section{h. Tuping}

Lagu ini juga merupakan lagu yang diambil dari lagu gamelan dimana lagu ini juga sudah tidak dimainkan lagi, sama halnya dengan lagu yang lain di atas.

\section{Fungsi Musik Tradisional Kuriding}

a. Sebagai sarana hiburan pribadi

Kuriding sebagai alat musik yaitu karena kuriding merupakan sebuah alat yang dapat menghasilkan bunyi dari dirinya sendiri sehingga kuriding dikategorikan sebagai alat musik. Kuriding pada zaman dahulu digunakan oleh masyarakat agraris sebagai alat untuk penghibur di sawah atau ladang, kegiatan ini dilakukan untuk mengusir rasa penat dan lelah pada saat melakukan kegiatan di sawah atau ladang.

Bunyi kuriding sendiri menghasilkan bunyi yang dapat memberikan rasa ketengangan bagi seseorang secara pribadi dan juga bagi orang lain yang mendengarnya. Kuriding dapat dikategorikan sebagai sebuah alat musik setelah saat ini ditinjau dari aspek bunyi dan musikalitas yang hadir pada alat tersebut. Oleh karena itu, kuriding ini merupakan alat musik yang dapat digunakan untuk menghibur diri secarfa pribadi pada saat waktu-waktu tertentu. 
b. Sebagai sarana presentasi estetis

Keindahan (estetika) oleh para seniman diwujudkan ke dalam bentuk sebuah karya seni. Bagaimana seni bisa lahir dengan sebuah proses kreatif, itu merupakan sebuah dorongan hasrat manusia untuk menghadirkan sebuah karya seni untuk dapat dinikmati keindahannya (Ratna, 2011: 12).

Kuriding juga dapat berfungsi sebagai sarana presentasi estetis(keindahan), dalam hal ini keindahan bunyi dalam sebuah pertunjukan, baik pertunjukan untuk menghibur diri sendiri dan juga menghibur orang lain yang mendengarkan pertunjukan kuriding. Mempertunjukan kuriding adalah sebuah upaya untuk memberikan edukasi dan juga sekaligus sebagai sebuah upaya untuk menghadirkan bentuk pertunjukan yang dapat berdiri sendiri sebagai sebuah musik.

Keindahan bunyi kuriding dapat dirasakan oleh indera pendengar setiap orang yang menyaksikan pertunjukan alat musik kuriding. Baik yang menyaksikan secara langsung maupun yang menyaksikan melalui media lain seperti youtube atau media sosial. Sehingga, sarana untuk menikmati musik kuriding bisa dilakukan dan dipertunjukan dimana saja dan tidak terbatas oleh ruang dan waktu.

c. Sebagai sarana pengikat solidaritas masyarakat

Kuriding dapat berfungsi sebagai media silaturahmi karena dengan memainkan kuriding secara bersama-sama akn dapat meningkatkan rasa kebersamaan diantara pemain kuriding. Rasa kebersamaan itu akan saling mengisi dan mengikat rasa persaudaraan diantara sesama dalam kehidupan bermasyarakat.

Kuriding sebagai alat musik tidak hanya sekedar sebagai media bunyi saja, tapi juga sebagai sarana untuk dapat berkumpul dan membaur dengan kondisi sosial masyarakat di lingkungan pemilik kuriding tersebut. Oleh karena itu, pentingnya silaturahmi dalam musik juga merupakan upaya untuk menjaga kestabilan hubungan komunikasi diantara sesama masyarakat.

\section{SIMPULAN}

\section{Kesimpulan}

Berdasarkan hasil penelitian dan pembahasan, dirumuskan simpulan sebagai berikut : a. yaitu sekitar tahun 1930an ketika Syamsuddin dianggap sudah berusia remaja, dan juga pada tahun-tahun setelah kemerdekaan yaitu tahun 1945 sudah diadakan acara bakuriding, dan juga dibuktikan dengan masih adanya peninggalan alat musik yang dimainkan sejak awal dahulunya, hingga sekarang yang masih dalam kondisi bisa dimainkan dan diperkirakan usia dari alat musik tersebut hampir mencapai seratus tahun karena dilihat dari warna kuriding tersebut yang sudah menghitam, tidak seperti Kuriding yang baru.

Tetapi dari wawancara yang saya lakukan, Iwie menuturkan bahwa sebelum Syamsuddin menikah dengannya, Syamsuddin pernah madam atau merantau ke daerah lain yang tidak diketahui nama daerahnya, namun daerah tersebut tidak di luar pulau Kalimantan. Namun, satu hal juga yang menjadi pertimbangan saya, dimungkinkan Kuriding bisa juga dipengaruhi oleh kebudayaan lain karena pada zaman dahulu khususnya kota Marabahan, yang merupakan salah satu titik perdagangan air di Kalimantan Selatan pada saat itu, yang berjarak hanya sekitar $60 \mathrm{~km}$ dengan kota Banjarmasin dimana Sungai Barito adalah akses utamanya. Tidak menutup kemungkinan Kuriding ini masuk melalui arus perdagangan pada dahulunya sebagai alat tukar sehingga Kuriding tersebut ada di Desa Ulu Benteng.

b. Perkembangan Musik Tradisional Kuri- 
ding di Desa Ulu Benteng dapat disimpulkan tidak berkembang, hal ini dibuktikan dengan hanya tersisa empat orang yang masih mampu untuk memainkan Kuriding tersebut. Namun Kuriding mengaalami perkembangan di Kalimantan Selatan, yaitu pada kelompok Saradipa Kuriding Sanggar Seribu Sungai Banjarmasin dengan dipelopori oleh Mukhlis Maman dan Ferry Kusmana serta saya sendiri juga terlibat disana. Kelompok ini sudah mampu menampilkan Kuriding sampai tingkat nasional di Jakarta pada Tanggal 5 mei 2014 di Galeri Indonesia Kaya Jakarta.

c. Pembelajaran Musik Tradisional Kuriding di Sekolah dapat diajarkan melalui mata pelajaran Seni Budaya, pada sub materi seni musik dengan kompetensi dasar apresiasi terhadap musik tradisional daerah setempat.

\section{Saran}

Berdasarkan kesimpulan di atas, peneliti mengajukan saran sebagai berikut :

a. Diharapkan kepada pemerintsah terkait agar turut menjaga kelestarian Musik Tradisional Kuriding sebagai aset kesenian daerahnya.

b. Perlunya pengenalan yang lebih mendalam kepada peserta didik tentang Kesenian Musik Tradisional kuriding sebagai identitas dan kekayaan budaya daerah.

c. Kepada calon tenaga pendidik mata pelajaran Seni Budaya di sekolah hendaknya selalu berusah untuk belajar kesenian daerah dan bersemangat dalam mengenalkan serta mengajarkan kesenian tersebut.

\section{DAFTAR SUMBER}

Maryanto, 2014. Tinjauan Etnomusikologi Musik Kuriding Suku Dayak Bakumpai Kabupaten Barito Kuala Kalimantan Selatan. Yogyakarta : Aswaja Pressindo. Najamudin, Muhammad. 2016. Musik Kuriding Kalimantan Selatan (Kajian Organologi). Universitas lambung Mangkurat.

Pradoko, Susilo, A.M. 2017. Paradigma-Paradigma Kualitatif. Yogyakarta: Charissa Publisher.

Ratna, Nyoman, Kutha. 2011. Estetika Sastra dan Budaya. Yogyakarta : Pustaka Pelajar.

Soedarsono, R. M. 2001. Seni Pertunjukan Indonesia di Era Globalisasi. Jakarta : Dirjen PT. Depdikbud.

Sugiyono. 2010. Metedologi Penelitian Pendidikan. Bandung : Alfabeta.

Sugiyono. 2013. Metedologi Penelitian Pendidikan. Bandung : Alfabeta

Taylor, J, Steven,. Bogdan, Robert,. \& DeVault, L, Marjorie. (2016). Introduction To Qualitative Research Methods. New Jersey : John Wiley and Sons, Inc.

Tjejep Rohendi, Rohidi. (2011). Metodologi Penelitian Seni. Semarang : Cipta Prima Nusantara. 